Paradoxically, the Court of Appeal has increased the importance of the waiver provision. The original rationale behind the redundancy exclusion was explained by Professor Grunfeld, Professor of Law, London School of Econonics, as being that "an employee taken on for a fixed period knows from the beginning that his job ends on a certain date ... The fixed term employee knows what is to come and is therefore in a position to plan ahead for himself"'. But such a view cannot tenably be expanded to cover an exclusion from Unfair Dismissal. The law at present provides for fair dismissal in relation to lacklustre performance in a probationary period, and the continuance of the arbitrary two-year fixed term rule operates merely as a loophole for an employer to evade the Act.

It is unrealistic to imagine that research workers can individually refuse the imposition of a waiver when there may be hundreds of other candidates willing to take up the post. Of course the practical solution is through collective negotiation

THE subject of meat eating is one that entrances gourmets, repels vegetarians, and attracts anthropologists. It has fascinated physiologists ever since the experiments on the fistulated stomach of Alexis St Martin by William Beaumont.

Something new happened recently: it started in a restaurant in Washington that was serving Pennsylvania rattlesnake meat to its patrons, thus reversing the balance of nature in which snakes bite hominids. Incredible as this would have seemed even as recently as 30 years ago, this venomous serpent is protected as an endangered species. An employee of the US Fish and Wildlife Service wrote a letter to the restauranteur, tactfully pointing out the act of trespass, whereupon the restaurant switched to Texas rattlesnakes for serving to its herpetophagic patrons.

All seemed well at first - except for the Texas snakes - but perhaps a conservationist intervention will soon be organised on their behalf. However, the news leaked out, whereupon the offending civil servant was fired by order of the Secretary of the Interior. A thunderous protest against the firing was mounted by lovers of Pennsylvania rattlesnakes and haters of dictatorial cabinet members, so that the Secretary hastily re-hired the snake-protector, bowing to the uproar from Congress, and from environmentalists, who are still seething over the betrayal of the snail darter.

It was time, I thought, for some general comments on meat eating, a mode of sustenance that involves a complex pattern of approvals and taboos. Probably none of us is without prejudice, distaste or downright rejection for some forms of meat that are relished by ethnic to abolish the waiver, but given the lack of unionisation and the ease of importing new research workers, this can only be a longterm aim. Meanwhile, even where a waiver is not utilised, employers mould their contracts to the law; a favourite device is the 21-month contract, which creates the problem of finance over the summer before the start of a new academic post.

An important question arises over multiple contracts: is it possible to amalgamate the cumulative period of a series of fixed term contracts to achieve a fixed term of two years? In Ioannou the Court of Appeal, in a part of the judgement that has not been overturned, held that it is only the 'final' contract which has to be considered. Only where this final contract is for a fixed term of two years or more can there be a valid waiver. Although lawyers would normally draw a distinction here between a 'renewal' or a 're-engagement', Lord Denning regarded this as "too fine a distinction for ordinary mortals". His approach was followed in the Employment Appeal Tribunal decision of Open

groups to which we do not belong. Nutritionally speaking, the proteins of various meats are quite similar in amino acid content, and are superior in this respect to vegetable proteins, but this does not affect their acceptance or rejection.

Avoidance of beef in India is one of the

\section{Carnivorous practices}

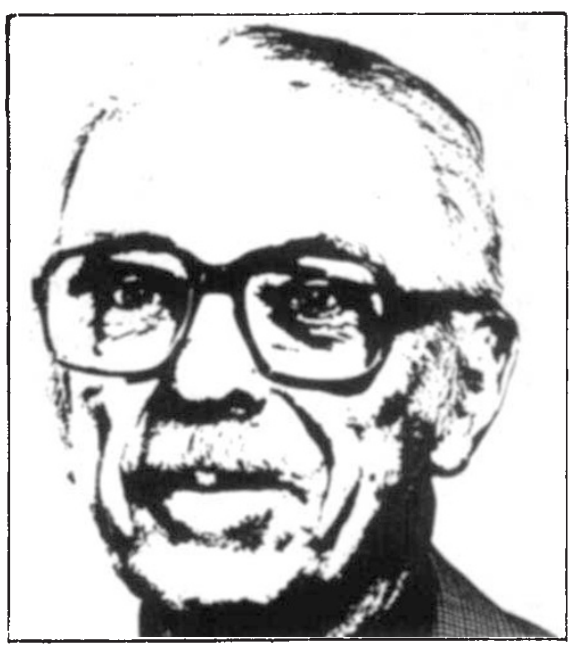

\section{THOMAS H. JUKES}

best-known taboos. One theory is that it originated when Brahmins renounced cattle sacrifice to improve their position in political rivalry with the Buddhists. The shunning of pork is centered in the Middle East, and the feelings of rejection can be intense enough that martyrs have chosen death rather than submitting to being forced to eat pork.
University $v$. Triesman [1978] ICR 524, where the employee was offered a post as a lecturer for a fixed period of 18 months.

However, this 'straightforward' view has strange consequences. If an employee starts with a 21 -month fixed term contract and is therefore unable to make a waiver, but then goes on to a two year renewal with a waiver, he will be unable to claim a redundancy payment. The first period will be blotted out, and no claim is possible.

This and many other legal puzzles leave the law in an uncertain state. There is still the faint chance of an appeal in Dixon to the House of Lords changing the law all over again, or even the possibility of major legislative change by the present government which has as yet given no precise indications as to the parameters of planned amending statutes. The only certainty is that the present law is in urgent need of an overhaul to resolve the waiver dilemma. Although this of course will do nothing to change the demand for short term contract workers, it may prevent some of the anxieties suffered by them.

It is often firmly asserted that the Jewish ban on pork originated as a protective measure against trichinosis that was based on intuitive and shrewd trial-and-error observations. This is contradicted by Simoons, F.J. Eat Not This Flesh (University of Wisconsin Press, Madison, 1961), who points out that Trichinella was unknown until the nineteenth century and was considered to be a harmless organism for 25 years after its discovery. It is unlikely that spoilage of pork by heat is the reason for the rejection. Temperatures in the Middle East are no higher than in many countries such as Southeast Asia, where pork has been a prized food for many centuries.

The evaluation of other possible reasons for the ban, such as distaste for the uncleanliness of pigs, is complicated by the fact that Jewish laws also banned the eating of 30 kinds of animal including some comparatively tidy creatures, such as snakes. Chickens, however, are on the approved menu, even though their eating habits are at least as unsanitary as those of pigs. Americans and Western Europeans, who avidly swallow live oysters, would recoil from eating dog, which is relished in Central Africa, China and Southeast Asia.

The eating of frogs and snails was formerly used to whip up feelings of xenophobic prejudice in England against the French. In riposte, the English were called 'limeys', but it seems difficult to arouse antipathies based on the consumption of fruit, and, in any case, limes prevent scurvy.

The new approach to the avoidance of foods, including meat, and especially beef, is based on arousing the fear of cancer. I shall discuss this, and more meat-eating matters next time. 